\title{
Prostaglandin F2 $\alpha$ promotes embryo implantation and development in the pig
}

\author{
Piotr Kaczynski¹, Monika Baryla¹, Ewelina Goryszewska¹, Stefan Bauersachs² \\ and Agnieszka Waclawik ${ }^{1}$ \\ 'Institute of Animal Reproduction and Food Research, Polish Academy of Sciences, Olsztyn, Poland and ${ }^{2}$ University \\ of Zurich, Vetsuisse Faculty, Clinic of Reproductive Medicine, Genetics and Functional Genomics, \\ Lindau, Switzerland \\ Correspondence should be addressed to A Waclawik; Email: waclawik@pan.olsztyn.pl
}

\begin{abstract}
Successful establishment and development of pregnancy requires proper communication between developing conceptuses and the maternal reproductive tract. Prostaglandins are key players involved in the regulation of reproductive processes in mammals including pigs. Due to its luteolytic action, prostaglandin F2-alpha (PGF2 $\alpha$ ) is mainly considered as an undesirable factor during early pregnancy. However, its content in the uterine lumen is elevated in pigs and other mammals. Recently, we reported an important role of PGF2 $\alpha$ in the endometrium during early pregnancy in the pig. Thus, the aim of the present study was to determine whether PGF2 $\alpha$ can act on porcine trophoblast and if so, to elucidate what effect it could exert. We detected increased expression of PGF2 $\alpha$ receptor during the implantation period (from day 14 until day 19 of pregnancy). Global gene expression profiling using microarrays and quantitative PCR studies revealed that PGF2 $\alpha$ acting on porcine trophoblast cells in vitro alters expression of genes potentially involved in processes related to implantation, such as cell proliferation, focal adhesion, extracellular matrix binding, cell migration, cytoskeleton organization, immune interactions, ion homeostasis and lipid metabolism. Using primary porcine trophoblast cells, we demonstrated that PGF2 $\alpha$ stimulated trophoblast cell proliferation and adhesion to extracellular matrix protein. This was likely mediated by mitogen-activated protein kinases (MAPK1/3) and focal adhesion kinase (FAK) since we observed increased phosphorylation of MAPK1/3 and FAK in trophoblast cells treated with PGF2 $\alpha$. To conclude, the present report indicates a novel role for PGF2 $\alpha$ in the porcine conceptus as a paracrine and autocrine factor supporting pregnancy establishment.
\end{abstract}

Reproduction (2018) 156 405-419

\section{Introduction}

The establishment and development of pregnancy in the pig, as in any mammalian species, requires proper communication between developing conceptuses and the intrauterine environment. This embryo-maternal dialog includes hormonal and immune interactions precisely controlled by hormones, cytokines, growth factors and other molecules interacting in endo-, paraand autocrine manners.

During the maternal recognition of pregnancy period, which occurs in pigs on days 11-12 of pregnancy, conceptuses secrete increased levels of estrogens that are one of the major conceptus signals for the establishment of pregnancy. This leads to the redirection of luteolytic prostaglandin F2 $\alpha$ (PGF2 $\alpha$ ) secretion from endocrine to exocrine (to the uterine lumen) mode and also affects the hormonal environment in the reproductive tract, resulting in prolonged lifespan of the corpus luteum $(\mathrm{CL})$ and, thereby, maintained progesterone (P4) synthesis (Bazer \& Thatcher 1977). The second phase of increased estrogen secretion occurs in pigs on day 15 of pregnancy and lasts until day 25 after fertilization (Geisert et al. 1990).

Key factors involved in the control of reproductive processes in mammals are prostaglandins (PGs). Their importanceforpregnancyestablishmentand development is shown by the fact that lack of PG synthesis leads to termination of pregnancy just before the implantation process in mammals such as pigs (Kraeling et al. 1985), cattle (Erdem \& Guzeloglu 2010) and rodents (Kennedy et al. 2007). Interestingly, intrauterine administration of prostaglandin synthase inhibitors resulted in improper conceptus elongation in sheep (Dorniak et al. 2011), which has a much different programming for conceptus growth compared to rapid trophoblast elongation in the pig. In contrast, PG synthesis inhibition does not affect elongation of porcine conceptuses (Geisert et al. 1986), but it does affect their survival during the attachment period (Kraeling et al. 1985) Prostaglandin E2 (PGE2) and PGF2 $\alpha$ are the major prostaglandins involved in reproductive functions in mammalian reproductive 
tracts. They act through their receptors: PTGER1-4 (PGE2 receptors isoforms $1-4)$ and PTGFR (PGF2 $\alpha$ receptor). The expression profiles of PTGER2 and PTGER4 were determined in porcine trophoblasts at different stages of development (Waclawik et al. 2013). However, the expression profile of PTGFR in porcine conceptuses during early pregnancy has not been studied yet. Interestingly, the expression of PGE2 and PGF $2 \alpha$ synthases is elevated both in porcine endometrium and in conceptuses during the maternal recognition of pregnancy and/or implantation (Waclawik et al. 2006, Waclawik \& Ziecik 2007). PGE2 has been described as playing a luteoprotective/luteotrophic role (Waclawik et al. 2008, 2009, Waclawik 2011) whereas PGF2 $\alpha$ has been mainly perceived as a luteolytic factor in sheep, cattle and pigs, as well as in rats, rabbit and hamsters (reviewed in McCracken et al. 1999). Thus, it could also have a detrimental effect in pregnancy development in mammals, including human, cattle, pigs and dogs (reviewed in Kaczyński et al. 2016). However, it should not be regarded as undesirable factor in pregnancy because elevated amounts of PGF2 $\alpha$ in the uterine lumen and/or its increased endometrial synthesis occur not only in pigs (Zavy et al. 1980, Waclawik et al. 2006) but also in other mammals including rodents, cattle, dogs and humans (Kennedy et al. 2007, Ulbrich et al. 2009, Wang et al. 2010, Vilella et al. 2013, Kowalewski et al. 2014). Moreover, a novel role for PGF2 $\alpha$ in the porcine endometrium during the peri-implantation period has been recently reported by our group, indicating that PGF2 $\alpha$ participates in pregnancy establishment by promoting angiogenesis and expression of genes involved in endometrial remodeling and embryomaternal communication (Kaczyński et al. 2016).

Previously we indicated that synthesis of PGF $2 \alpha$ during the implantation period is elevated both in the porcine endometrium and the conceptus (Waclawik et al. 2006, Waclawik \& Ziecik 2007). Recently, we also elucidated the mechanism of PGF2 $\alpha$ action in the endometrium (Kaczynski \& Waclawik 2013, Kaczyński et al. 2016). Hence, the question arose whether PGF $2 \alpha$ can act through its receptor in the conceptus and if so, what could be the role of PGF $2 \alpha$ in porcine trophoblast cells? During the period when the endometrium becomes receptive for embryo implantation, both the uterine luminal epithelium and conceptus cells simultaneously initiate the adhesion cascade (Geisert et al. 2015). Attachment of trophoblast cells to luminal epithelium is supported by interactions between integrins and extracellular matrix (ECM) proteins. Integrin receptors (AVB1, AVB3, AVB5 and A4B1) are able to bind to the RGD (Arg-Gly-Asp) sequence present in osteopontin, fibronectin and vitronectin proteins (Bowen et al. 1996, Johnson et al. 2003). Our studies indicate the important role of PGE2 in activation of intracellular pathways in porcine trophoblast cells related to adhesion (mitogen-activated protein kinases 1/3 - MAPK1/3); FAK and intracellular adhesion molecule 1 (ICAM1) and promotion of trophoblast adhesion to ECM proteins (Waclawik et al. 2013). Moreover, we demonstrated a stimulatory effect of PGE2 on trophoblast cell estradiol$17 \beta$ synthesis (Waclawik et al. 2013). It has been shown that lack of PGs (PGE2 and PGF2 $\alpha$ ) decreased adhesion of mouse blastocysts and JEG-3 spheroids to human luminal epithelial cells (Vilella et al. 2013). However, the mechanisms by which PGF2 $\alpha$ may stimulate trophoblast cell adhesion to ECM proteins remain unknown. Furthermore, despite elevated conceptus and endometrial synthesis of PGF $2 \alpha$, its role in the proliferative capacities of trophoblast cells and activation of intracellular pathways is still unresolved.

Based on data in the literature including results from our previous studies, we hypothesized that during early pregnancy in the pig, PGF $2 \alpha$ acting through its receptor in trophoblast cells activates intracellular pathways important for the implantation process. Thus, the objectives of the present study were (i) to determine the expression profile of the PTGFR gene and protein in porcine conceptuses/trophoblasts at different stages of development; (ii) to investigate the effect of PGF2 $\alpha$ on global gene expression profiles in porcine primary trophoblast cells in vitro; (iii) to study the effect of PGF $2 \alpha$ on trophoblast cell adhesion and proliferation and (iv) to evaluate whether PGF $2 \alpha$ may activate MAPK1/3 and FAK in porcine trophoblast cells, which could be involved in adhesion and/or proliferation processes.

\section{Materials and methods}

All procedures involving animals were conducted in accordance with the national guidelines for agricultural animal care and were approved by the Animal Ethics Committee, University of Warmia and Mazury in Olsztyn, Poland, permission No. 36/2012.

\section{Experiment 1: PTGFR mRNA and protein expression in the porcine conceptus/trophoblast}

Gilts after two natural estrous cycles were bred at the onset of estrus (day 0) and then $12 \mathrm{~h}$ and $24 \mathrm{~h}$ later. Pregnant gilts were slaughtered at the local abattoir. Conceptuses at the preimplantation stage were flushed from the uterine horns with $20 \mathrm{~mL}$ of sterile PBS $(137 \mathrm{mM} \mathrm{NaCl}, 27 \mathrm{mM} \mathrm{KCl}$, $10 \mathrm{mM} \mathrm{Na}_{2} \mathrm{HPO}_{4}$ and $2 \mathrm{mM} \mathrm{KH}_{2} \mathrm{PO}_{4}, \mathrm{pH}$ 7.4). Conceptuses/ trophoblasts at the implantation and early placentation stage were dissected from the endometrium. Considering the days of pregnancy and morphology of trophoblasts, the conceptus samples derived from thesameanimal werepooled and classified into the following groups: days 10-12 (preimplantation stage; spherical and tubular forms, $n=5$ ), days 14-15 (beginning of attachment/implantation; filamentous forms, $n=5$ ), days 16-19 (filamentous forms; implantation stage, $n=7$ ) and days 
20-25 (chorion which originates from trophoblast; the onset of placenta development; $n=10$ ). Dissections of trophoblast tissues from conceptuses were performed since day 18 post mating (Waclawik et al. 2013). Therefore, expression of PTGFR was analyzed in 10- to 17-day conceptuses and 18- to 25-day trophoblast tissues. Collected conceptuses/trophoblasts were snap-frozen in liquid nitrogen and stored at $-80^{\circ} \mathrm{C}$ until gene and protein expression analyses.

\section{RNA isolation and CDNA synthesis}

Collected tissues were homogenized in $800 \mu \mathrm{L}$ of Fenozol buffer (A\&A Biotechnology, Gdansk, Poland) using Lysing Matrix D beads (MP Biomedicals, Santa Ana, USA) and Fast Prep homogenizer (MP Biomedicals). RNA was isolated from tissues with RNA Mini Kit (A\&A Biotechnology), according to the manufacturer's protocol. Integrity and concentration of isolated RNA was analyzed by using Agilent 2100 Bioanalyzer (Agilent Technologies). Additionally, concentration of RNA was measured with NanoDrop spectrophotometer (Thermo Fisher Scientific). To generate cDNA for qPCR reaction, total RNA sample $(1 \mu \mathrm{g})$ was reverse-transcribed with MultiScribe Reverse Transcriptase kit (Thermo Fisher Scientific) according to the manufacturer's protocol. cDNA samples were stored in $-80^{\circ} \mathrm{C}$ for further quantitative PCR (qPCR) analyses.

\section{Quantitative $P C R$}

Analysis of PTGFR gene expression in conceptuses was performed as described previously (Kaczynski \& Waclawik 2013). Reverse-transcribed cDNA $(3.5 \mu \mathrm{L})$ was added to the reaction mixture: $12.5 \mu \mathrm{L}$ Power SYBR Green master mix (Thermo Fisher Scientific), $2.5 \mu \mathrm{L}$ of each sense and antisense primer ( $1 \mu \mathrm{M}$; Supplementary Table 1 , see section on supplementary data given at the end of this article) and $4 \mu \mathrm{L}$ of nuclease-free water. Specific primers used for realtime RT-PCR are listed in Table 1. The PCR program for PTGFR gene was performed as follows: initial denaturation $\left(95^{\circ} \mathrm{C}, 10 \mathrm{~min}\right)$ followed by 36 cycles of denaturation $\left(95^{\circ} \mathrm{C}\right.$; $15 \mathrm{~s})$, annealing and elongation $\left(60^{\circ} \mathrm{C} ; 1 \mathrm{~min}\right)$. For actin beta $(A C T B)$, cyclophilin A (PPIA) and glyceraldehyde-3phosphate dehydrogenase (GAPDH) amplification, the PCR program was initial denaturation $\left(95^{\circ} \mathrm{C}, 10 \mathrm{~min}\right)$ followed by 36 cycles of denaturation $\left(95^{\circ} \mathrm{C}, 15 \mathrm{~s}\right)$, annealing $\left(55^{\circ} \mathrm{C}, 30 \mathrm{~s}\right)$ and elongation $\left(72^{\circ} \mathrm{C}, 1 \mathrm{~min}\right)$. After PCR, melting curves were acquired by gradual increases in the temperature from 60 to $95^{\circ} \mathrm{C}$ to ensure that a single product was amplified in the $\mathrm{PCR}$ reaction. All real-time PCR reactions were performed with Applied Biosystems 7900HT Real-Time PCR system (Life Technologies). Gene expression was estimated using real-time PCR Miner software (Zhao \& Fernald 2005). Stability of the reference genes in the porcine conceptuses was assessed using the statistical algorithms Normfinder 2.0 (Andersen et al. 2004). Three of the following reference genes were analyzed: GAPDH, $P P I A$ and $A C T B$. The most stable combination of reference genes was the geometrical mean of $A C T B$ and GAPDH expression values.

\section{Protein isolation}

Conceptuses (days 10-17)/trophoblasts (days 18-25) collected from pregnant gilts were homogenized on ice in $150 \mu \mathrm{L}$ of homogenization buffer $(50 \mathrm{mM}$ Tris- $\mathrm{HCl}, \mathrm{pH} 8.0 ; 150 \mathrm{mM}$ $\mathrm{NaCl}, 1 \mathrm{mM}$ EDTA) supplemented with Protease Inhibitor Cocktail (Sigma-Aldrich). Homogenates were then centrifuged for $15 \mathrm{~min}$ at $800 \times \mathbf{g}$ at $8^{\circ} \mathrm{C}$ and stored at $-80^{\circ} \mathrm{C}$ for further analysis. The protein concentration was determined with Bradford Assay. PTGFR protein abundance in conceptus homogenates was assessed by Western blot analysis.

\section{Western blot}

Western blot analysis for PTGFR protein expression in conceptuses was performed as described previously (Kaczynski \& Waclawik 2013). Briefly, equal amounts of protein samples $(40 \mu \mathrm{g})$ were separated on $10 \%$ SDS PAGE. Proteins were electroblotted onto $0.2 \mathrm{~mm}$ PVDF membrane. After blocking in $5 \%$ nonfat dry milk, the blots were incubated overnight at $4{ }^{\circ} \mathrm{C}$ with primary antibodies (Table 2) and afterward with 1:20,000 dilution of secondary anti-rabbit horseradish peroxidase antibodies (Bio-Rad Laboratories) for $90 \mathrm{~min}$ at room temperature. Immune complexes were visualized using Clarity Western ECL Substrate (Bio-Rad). Sample loading was standardized to expression of GAPDH. Signal was quantitated using Versa-Doc 4000M imaging system (BioRad Laboratories).

\section{Experiment 2: The effect of PGF2 $\alpha$ on global gene expression profile in porcine trophoblast cells}

\section{Incubation of the porcine primary trophoblast cells with PGF $2 \alpha$}

Porcine trophoblast cells were isolated as described previously (Waclawik et al. 2013). Crossbred gilts $(n=5)$ of similar age and genetic background were inseminated and slaughtered on day 15 of pregnancy at the local abattoir. Conceptuses were recovered from uteri by gentle flushing of each uterine horn with medium M199 (Sigma-Aldrich) containing 0.1\% (wt/vol) bovine serum albumin (BSA), penicillin (100lU/ $\mathrm{mL}$, Sigma-Aldrich) and streptomycin $(100 \mu \mathrm{g} / \mathrm{mL}$, SigmaAldrich), warmed up to $37^{\circ} \mathrm{C}$. Conceptuses were separated from flushing medium by centrifugation for $10 \mathrm{~min}$ at $150 \times \mathbf{g}$ at $8^{\circ} \mathrm{C}$. Trophoblast tissue was dissected from the embryonic disk region. Trophoblast cells were then non-enzymatically dispersed by pipetting. After dispersion, the cells were washed three times with sterile medium M199 with antibiotics and $0.1 \% \mathrm{BSA}$, re-suspended in sterile M199 containing antibiotics and $5 \%$ newborn calf serum (NCS, Sigma-Aldrich) and seeded on human collagen I-coated 6-well plates (BioCoat 356400; BD Biosciences). Adherent cells were washed with PBS $48 \mathrm{~h}$ after plating to remove contaminating aggregates. Additionally, to assess the purity of cell cultures, isolated cells were stained for the presence of the trophoblast marker cytokeratin as described previously (Blitek et al. 2012). After reaching $70-80 \%$ confluence, the cells were washed with sterile PBS. The following treatments were performed: PGF2 $\alpha$ (100 nM; $1 \mu \mathrm{M}$; Sigma-Aldrich) and control (medium M199 
Table 1 Primer sequences and assays used in qPCR analyses.

\begin{tabular}{|c|c|c|c|}
\hline Gene & Primer sequence/TaqMan Assay ID & RefSeq ID/GenBank accession no. & Reference \\
\hline PTGFR & $\begin{array}{l}\text { Sense: 5'-TCAGCAGCACAGACAAGG-3 } \\
\text { Antisense: 5'-TTCACAGGCATCCAGATAATC-3 }\end{array}$ & NM_214059 & Kaczynski \& Waclawik (2013) \\
\hline$A C T B$ & $\begin{array}{l}\text { Sense: 5'-ACATCAAGGAGAAGCTCTGCTACG-3' } \\
\text { Antisense: 5'-GAGGGGCGATGATCTTGATCTTCA-3' }\end{array}$ & U07786 & Kaczynski \& Waclawik (2013) \\
\hline GAPDH & $\begin{array}{l}\text { Sense: 5'-CAGCAATGCCTCCTGTACCA-3' } \\
\text { Antisense: 5-GATGCCGAAGTTGTCATGGA-3' }\end{array}$ & AF017079 & Kaczynski \& Waclawik (2013) \\
\hline PPIA & $\begin{array}{l}\text { Sense: 5'-TAACCCCACCGTCTTCTT-3' } \\
\text { Antisense: 5'-TGCCATCCAACCACTCAG-3' }\end{array}$ & AY266299.1 & Kaczynski \& Waclawik (2013) \\
\hline ADAM9 & Ss03373282_m1 & AF069646.1 & - \\
\hline AGER & Ss03390846_g1 & EU282357.1 & - \\
\hline$A M B P$ & Ss03374771_m1 & AK232748.1 & - \\
\hline$B G N$ & Ss03375454_u1 & AF159382.1 & Kaczyński et al. (2016) \\
\hline$B M P 2$ & Ss03373798_g1 & AY669080 & - \\
\hline DECR1 & Ss01051816_m1 & AK230726.1 & - \\
\hline IL1A & Ss03391335_m1 & X52731.1 & Kaczyński et al. (2016) \\
\hline IL6 & Ss03384604_u1 & AF309651.1 & Kaczyński et al. (2016) \\
\hline IL6R & Ss03394904_g1 & & \\
\hline KNG1 & Ss03373690_m1 & AY321363.1 & - \\
\hline LPAR1 & Ss03377225_u1 & AK344044.1 & - \\
\hline MASP1 & Ss04246770_m1 & GU810082.1 & - \\
\hline MFGE8 & Ss03390111_m1 & AK233926.1 & - \\
\hline MMP2 & Ss03394318_m1 & AF295805.1 & - \\
\hline MMP9 & Ss03392100_m1 & DQ132879.1 & Kaczyński et al. (2016) \\
\hline PROX1 & Ss04246028_m1 & EF486324.1 & - \\
\hline S100G & Ss03382848_u1 & L13068.1 & - \\
\hline SLCO2A1 & Ss03390713_m1 & NM_001123195 & - \\
\hline STC2 & Ss03389624_m1 & AK349078.1 & - \\
\hline TGFB3 & Ss03394352_m1 & X14150.1 & Kaczyński et al. (2016) \\
\hline THBS1 & Ss03373620_m1 & AM238691.1 & - \\
\hline TLR3 & Ss03388861_m1 & AB111939.1 & - \\
\hline$V T N$ & Ss03382603_u1 & AK232304.1 & - \\
\hline ACTB & Ss03376081_u1 & AK237086.1 & Kaczyński et al. (2016) \\
\hline PPIA & Ss03394782_g1 & AY266299.1 & Kaczyński et al. (2016) \\
\hline GAPDH & Ss03375435_u1 & NM_001206359.1 & Kaczyński et al. (2016) \\
\hline
\end{tabular}

with vehicle). Treated cells were incubated for $24 \mathrm{~h}$ at $37^{\circ} \mathrm{C}$ in humidified atmosphere containing $95 \%$ air and $5 \% \mathrm{CO}_{2}$. After incubation, culture media were collected and frozen. Cells were lysed with Fenozol buffer (A\&A Biotechnology), harvested and stored at $-80^{\circ} \mathrm{C}$ until isolation of RNA.

\section{Global gene expression profiling by using expression microarrays}

Total RNA was isolated from trophoblast cell lysates as described in Experiment 1 and destined for downstream analyses: global gene expression profiling (expression microarray analysis) and qPCR. Microarray analysis was performed starting from $100 \mathrm{ng}$ total RNA isolated from trophoblast cells after in vitro experiment (Experiment 2). Cy3labeled cRNA was produced with the Low-Input Quick Amp Labeling Kit, one-color (Agilent Technologies) and hybridized to the Agilent $4 \times 44 \mathrm{k}$ Porcine Gene Expression microarrays (G2519F-026440) according the manufacturer's instructions. Hybridized and washed slides were scanned at $2 \mu \mathrm{m}$ resolution with an Agilent DNA Microarray Scanner (G2505C; Agilent Technologies). Image processing was performed with Feature Extraction Software 10.5.1.1 (Agilent Technologies). Signals were filtered based on 'well above background' flags (detection in three of four samples) and normalized with the
BioConductor package VSN (Huber et al. 2002). For quality control, normalized data were analyzed with a distance matrix and a heatmap based on pairwise distances (BioConductor Package Geneplotter). Differentially expressed genes (DEGs) were identified in the contrast (pairwise comparison) 'PGF2 $\alpha$ treated cells' vs 'vehicle-treated cells' using the BioConductor package LIMMA (Linear Model for Microarray Analysis) (Smyth 2004). Low number of genes showing expression differences leads to a too strong correction of nominal $P$-values and a very low power to detect true DEGs (Hackstadt \& Hess 2009). Regarding the sensitivity problem of the FDR in case of a low number of DEGs, the cut-off values were set as follows: $\geq 1.2$ fold difference in expression values with a $P$-value less than 0.05 . Significant probes were annotated based on mapping of the probe sequences (60 nt sequences) to the porcine genome (SusScrofa 11.1). Known and potential human ortholog or homolog genes were assigned using a custom ortholog annotation database (Mammalian Ortholog and Annotation Database, MOAdb; J T Bick, S E Ulbrich and S Bauersachs, unpublished data). If a gene in the list was represented by more than one probe sequence, the mean fold-change and $P$-value were calculated. To visualize the distribution of expression signals of DEGs among samples, hierarchical clustering using Pearson correlation distance was performed using Multiexperiment Viewer software (MeV) (Saeed et al. 2003). 
Table 2 List of antibodies used in Western blot analyses and immunolocalization experiments.

\begin{tabular}{|c|c|c|c|c|c|}
\hline $\begin{array}{l}\text { Peptide/Protein } \\
\text { target }\end{array}$ & Antigen sequence & Name of antibody & $\begin{array}{l}\text { Manufacturer, catalog no., } \\
\text { or name of source }\end{array}$ & $\begin{array}{l}\text { Species raised in } \\
\text { monoclonal or } \\
\text { polyclonal }\end{array}$ & Dilution used \\
\hline PTGFR & $\begin{array}{l}\text { QRFRQKSKASFLLLASGLVITDFFGHLI } \\
\text { NGAIAVFVYASDKEWIRFDQSNVLCSI }\end{array}$ & PGF2aR antibody (H-55) & $\begin{array}{l}\text { Santa Cruz Biotechnology, } \\
\text { sc-67029 }\end{array}$ & Rabbit, polyclonal & $1: 50$ \\
\hline MAPK1/3 & N/A & p44/42 MAPK (Erk1/2) antibody & Cell Signaling, $\# 9102 \mathrm{~S}$ & Rabbit, polyclonal & $1: 300$ \\
\hline Phospho-MAPK $1 / 3$ & N/A & $\begin{array}{l}\text { Phospho-p44/42 MAPK (Erk1/2) } \\
\text { (Thr202/Tyr204) antibody }\end{array}$ & Cell Signaling, \#9101 & Rabbit, polyclonal & $1: 300$ \\
\hline FAK & N/A & FAK antibody & Cell Signaling, \#3285S & Rabbit, polyclonal & $1: 300$ \\
\hline Phospho-FAK & $\mathrm{N} / \mathrm{A}$ & Phospho-FAK (Tyr397) antibody & Cell Signaling, \#3283 & Rabbit, polyclonal & $1: 300$ \\
\hline Cytokeratin & $\mathrm{N} / \mathrm{A}$ & Anti-Pan Cytokeratin antibody & Sigma-Aldrich, C 9687 & Mouse monoclonal & $1: 50$ \\
\hline Anti-rabbit HRP & N/A & $\begin{array}{l}\text { Immun-Star Goat Anti-Rabit } \\
\text { (GAR)-HRP Conjugate }\end{array}$ & $\begin{array}{l}\text { Bio-Rad Laboratories, } \\
\# 170-5046\end{array}$ & Goat, polyclonal & $1: 20,000$ \\
\hline Anti-mouse & N/A & $\begin{array}{l}\text { Cy3 AffiniPure Donkey } \\
\text { Anti-Mouse IgG }\end{array}$ & $\begin{array}{l}\text { Jackson ImmunoResearch, } \\
\quad \# 715-165-150\end{array}$ & Donkey, polyclonal & 1:1000 \\
\hline
\end{tabular}

\section{Functional annotation of microarray data}

Lists of DEGs generated by LIMMA analysis were used as input data for functional annotation. To study the effect of PGF $2 \alpha$ on the global gene expression profile in trophoblast cells, opensource and commercial software was applied. The Database for Annotation, Visualization and Integrated Discovery (DAVID) (Huang et al. 2009a,b) was used to calculate the fold enrichment of identified gene ontology (GO) terms using following databases: Functional Categories (UP_KEYWORDS); gene ontology Biological Process (GOTERM_BP_FAT), Cellular Component (GOTERM_CC_FAT), Molecular Function (GOTERM_MF_FAT); General Annotations (SP_COMMENT); Pathways (BIOCARTA; KEGG PATHWAY); Protein Domains (INTERPRO) and Protein Interactions (UCSC_TFBS). Results generated by DAVID were summarized in tabular format. Topp Cluster software (Kaimal et al. 2010) was used to identify gene ontologies enriched by DEGs and to generate a network showing the shared and list-specific functional features. Results were summarized in tabular format and visualized by interaction network. To identify signaling pathways, molecular networks and biological functions for DEGs Ingenuity Pathway Analysis (IPA; v. 01.12; Qiagen) were used. Results were summarized in tabular and in graphic formats.

\section{Validation of microarray results}

To verify results obtained in microarray analysis we validated the expression of ADAM9, AGER, AMBP, BMP2, DECR1, IL1A, KNG1, LPAR1, MASP1, MFGE8, MMP2, PROX1, S100G, SLCO2A1, STC2, THBS1, TLR3 and VTN genes using real-time RT-PCR method. Additionally, based on our previous studies (Kaczyński et al. 2016) and literature data, we studied whether PGF2 $\alpha$ affected the expression of BGN, IL6, IL6R, MMP9, TGFB3, TIMP1 and TIMP2 genes. Based on microarray results, we also decided to evaluate the gene expression profile of MMP9 in porcine conceptuses (days 10-17)/trophoblasts (days 18-25) throughout pregnancy development. cDNA was generated from RNA isolated from trophoblast cells as described in Experiment 1. Real-time RT-PCR was performed using TaqMan assays (Thermo Fisher Scientific; Table 1) according to the manufacturer's protocol. Results from qPCR were analyzed as described in Experiment 1. Stability of the reference genes in the porcine trophoblast cells was assessed using the statistical algorithm Normfinder 2.0 (Andersen et al.
2004). Three reference genes were analyzed namely GAPDH, PPIA and ACTB. The most stable combination of reference genes was the geometrical mean of $A C T B$ and GAPDH expression values.

\section{Experiment 3: The effect of PGF2 $\alpha$ on trophoblast cell adhesion and proliferation}

Porcine primary trophoblast cells were isolated as described previously (Waclawik et al. 2013) with some modifications. Briefly, recovered conceptuses were washed three times with medium M199 supplemented with 5\% (v/v) NCS and $0.1 \%$ $(\mathrm{m} / \mathrm{v})$ BSA. Subsequently, trophoblast tissue underwent mild digestion in $0.25 \%$ trypsin solution (Biomed, Lublin, Poland) for $30 \mathrm{~min}$ at $37^{\circ} \mathrm{C}$. After digestion, solution was neutralized with M199 supplemented with $10 \%(\mathrm{v} / \mathrm{v})$ NCS. Cells were then centrifuged at $150 \times \mathbf{g}$ for $10 \mathrm{~min}$ and washed three times with medium M199 supplemented with 5\% (v/v) NCS. After washing, the cells were re-suspended in medium M199 with $1 \%(\mathrm{v} / \mathrm{v})$ NCS. Viability and cell number was assessed with trypan blue dying.

For adhesion assay, cells $\left(1 \times 10^{6}\right.$ cells $\left./ \mathrm{mL}\right)$ were preincubated with medium M199 containing vehicle $(0.01 \%$ ethanol) or PGF2 $\alpha(100 \mathrm{nM}, 1 \mu \mathrm{M})$ with/without $50 \mu \mathrm{M}$ of PTGFR antagonist (AL8810, Sigma-Aldrich) for $30 \mathrm{~min}$ at $37^{\circ} \mathrm{C}$. Subsequently, $100 \mu \mathrm{L}$ of each cell suspension was transferred onto Millicoat Cell Adhesion Strips coated with human fibronectin (ECM101; Millipore) and incubated for $3 \mathrm{~h}$ at $37^{\circ} \mathrm{C}$. All treatments were performed in triplicates. After incubation, cell adhesion was measured using colorimetric method accordingly to the manufacturer's protocol.

Cells used in proliferation assay were re-suspended in culture medium (M199 supplemented with 5\% NCS) in concentration $5 \times 10^{4} \mathrm{cell} \mathrm{s} / \mathrm{mL}$. After attachment, the cells were incubated for $48 \mathrm{~h}$ at $37^{\circ} \mathrm{C}$ in humidified atmosphere $\left(95 \%\right.$ air, $\left.5 \% \mathrm{CO}_{2}\right)$ with medium M199 containing vehicle $(0.01 \%$ ethanol) or PGF2 $\alpha$ $(100 \mathrm{nM}, 1 \mu \mathrm{M})$ or stable PGF2 $\alpha$ analog (fluprostenol; $100 \mathrm{nM}$, $1 \mu \mathrm{M})$ with/without $50 \mu \mathrm{M}$ of PTGFR antagonist (AL8810). Based on our previous results (Kaczyński et al. 2016), 20\% NCS was used as a positive control. After $48 \mathrm{~h}$ of treatment, proliferation was determined using the Cell Titer 96 Aqueous One Solution Proliferation Reagent (Promega) according to the manufacturer's instructions. Experiments were repeated six times in triplicates. Fold difference was determined by dividing 
the absorbance obtained by PGF2 $\alpha$-treated cells (with/without inhibitors) by the absorbance obtained by vehicle-treated cells.

\section{Experiment 4: Effect of PGF2 $\alpha$ on downstream targets potentially involved in porcine trophoblast cells adhesion and proliferation}

To determine the protein expression of downstream targets of PGF2 $\alpha$ involved in porcine trophoblast cells adhesion and proliferation, we used previously described (Waclawik et al. 2013) in vitro model in which primary trophoblast cells were incubated for $24 \mathrm{~h}$ with either vehicle $(0.01 \%$ ethanol) or PGF2 $\alpha$ $(100 \mathrm{nM}, 1 \mu \mathrm{M})$ in the presence/absence of $50 \mu \mathrm{M}$ AL8810. After incubation, cells were lysed with RIPA buffer (PBS; $\mathrm{pH} 7.4 ; 1 \%$ Triton X-100; $0.5 \%$ sodium deoxycholate; $0.1 \%$ sodium dodecyl sulfate; $1 \mathrm{mM}$ EDTA) containing Protease Inhibitor Cocktail (Sigma-Aldrich) and Phosphatase Inhibitor Cocktail 2 (SigmaAldrich). Content of MAPK1/3, pMAPK1/3, FAK and pFAK in cell homogenates was determined using Western blot and was normalized against GAPDH expression. Phosphorylation of MAPK and FAK protein was calculated by dividing the relative content of phosphorylated to non-phosphorylated protein.

\section{Western blot}

MAPK1/3 and FAK protein phosphorylation was evaluated using Western blot analysis as described previously (Waclawik et al. 2013). Briefly, equal amounts of protein samples (18 $\mu \mathrm{g})$ from conceptus cell lysates were separated on $10 \%$ SDS PAGE. Proteins were electroblotted onto $0.2 \mathrm{~mm}$ PVDF membrane. After blocking in 5\% BSA, blots were incubated overnight at $4{ }^{\circ} \mathrm{C}$ with primary antibodies (Table 2) and afterwards with 1:20,000 dilution of secondary anti-rabbit horseradish peroxidase antibodies (Bio-Rad Laboratories) for $90 \mathrm{~min}$ at room temperature. Immune complexes were visualized using Clarity Western ECL Substrate (Bio-Rad). Sample loading was standardized to expression of GAPDH. Signal was quantitated using Versa-Doc 4000M imaging system (BioRad Laboratories).

\section{Statistical analysis}

Results from in vitro experiments (cell adhesion and proliferation assays), Western blot and qPCR studies were analyzed by one-way ANOVA followed by Tukey's test. All statistical analyses were conducted using GraphPad PRISM v. 6.01 software (GraphPad Software Inc.).

\section{Results}

\section{Experiment 1: Expression of PTGFR gene and protein increases in the conceptus/trophoblast during the implantation period}

Expression of PTGFR mRNA was elevated in conceptuses/trophoblasts from day 14 until day 19 of pregnancy (the implantation period; $P<0.05$ ) compared with conceptuses/trophoblasts on days 10-12 (the preimplantation period). The highest expression of PTGFR mRNA was observed in conceptuses/trophoblasts from days 16 to 19 of pregnancy (Fig. 1A) and was 48-fold greater than that in conceptuses/trophoblasts from days 10 to 12 of pregnancy $(P<0.05)$. PTGFR protein expression was elevated at the implantation period (days 14-15, 16-19 of pregnancy) when compared to later stage (days 20-25 of pregnancy; $P<0.05$; Fig. 1B). Expression of PTGFR protein in day 10-12 conceptuses was not evaluated due to insufficient amount of material for both gene and protein analyses. Thus, in collected material only expression of PTGFR gene was possible to analyze.

\section{Experiment 2: Effect of PGF2 $\alpha$ on global gene expression profile in porcine trophoblast cells}

\section{Characterization of trophoblast cells}

The purity of the isolated cells was assessed by the evaluation of the presence of the trophoblast marker cytokeratin and cell morphology. Isolated trophoblast cells presented uninuclear morphology (Supplementary Fig. 1A). Positive immunoreaction for cytokeratin confirmed the epithelial phenotype of trophoblast cells (Supplementary Fig. 1B). Antiserum-specific isotype control (negative control) used at the same dilution and protein concentration as the primary antibody is shown in Supplementary Fig. 1B (lower-left panel). Purity of cell cultures was assessed at $98 \%$.

\section{Global gene expression profiling by using expression microarrays}

The porcine trophoblast cells' response toward the PGF2 $\alpha$ treatment was characterized using a porcine Agilent microarray assay. Differential gene expression between the two experimental groups ('PGF2 $\alpha$-treated cells' vs 'vehicle-treated cells') was evaluated. The number of detected probes passing the filters was 27045 . Pairwise distance analysis based on all detectable probes revealed grouping replicates, but differences between PGF2 $\alpha$-treated and vehicle-treated samples are also indicated in the heat map (Supplementary Fig. 2). Using LIMMA package, 810 probes were found as differentially regulated (fold-change $</>1.2 ; P<0.05$; Supplementary Table 1). Annotation of probe sequences revealed 576 DEGs (216 downregulated, 360 upregulated) affected by PGF $2 \alpha$. The five DEGs showing highest upregulation in the pairwise comparison 'PGF2 $\alpha$-treated cells' vs 'vehicle-treated cells' were obtained for the following genes: S100G (3.9-fold), NPEPPS (2.6-fold), PDE1B (2.5fold), KNG1 (2.3-fold), AMBP (2.0-fold), whereas the five most downregulated genes (suppressed by PGF $2 \alpha$ ) were SELENBP1 (-1.8-fold), DIO1 (-1.8-fold), ENTPD8 (-1.8fold), LYZ (-1.7-fold), FMO1 (-1.6-fold). Hierarchical clustering of the obtained DEGs based on Pearson correlation revealed treatment grouping of analyzed samples with two main distinct clusters of genes with uniform distribution of expression signals (Fig. 2). 


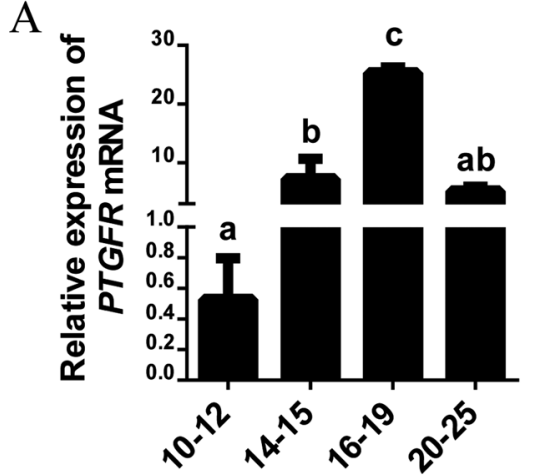

B

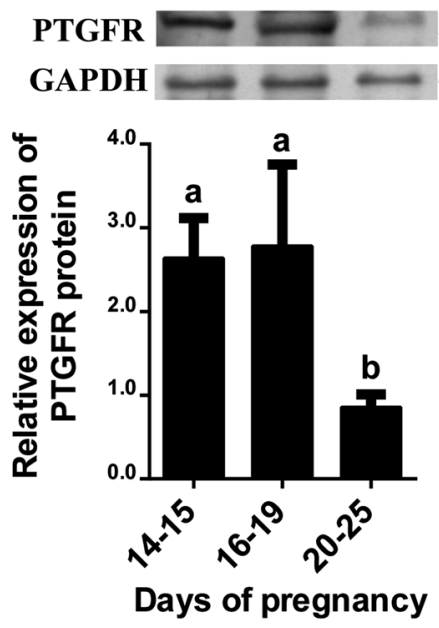

Figure 1 Expression of PTGFR mRNA (A) and protein (B) in the porcine conceptuses/trophoblasts at different stages of development. The representative samples of Western blots are shown in the upper panels. Data are represented as the mean \pm S.E.M. Bars with different letter differ significantly $(P<0.05)$.

\section{Functional annotation of microarray data}

Functional terms enriched for upregulated and downregulated DEGs from both experimental groups were identified by DAVID analysis. For upregulated DEGs, DAVID identified 83 functional annotation clusters with enrichment scores from 1.04 up to 3.96 (Supplementary Table 2), whereas for downregulated DEGs, 62 functional annotation clusters were identified with enrichment scores from 1.06 up to 6.79 (Supplementary Table 3). The most interesting functional terms of overrepresented annotation clusters enriched for upregulated genes were related to focal adhesion, cell migration, hypoxia, response to fibroblast growth factor (FGF2) and transforming growth factor beta (TGFB) and regulation of cell proliferation and MAPK cascade (Table 3). Terms overrepresented by downregulated genes were mainly related to fatty acid biosynthetic process, cell migration, anion transport, response to interferon gamma and placenta development (Table 3). Complete results from functional annotation clustering were summarized in Supplementary Tables 2 and 3.
Using ToppCluster software, GO terms (biological process, cellular component and molecular function) and pathways (KEGG) enriched by DEGs were identified and summarized in tabular format (Supplementary Table 4). Similarly, as in DAVID analysis, overrepresented terms were related to processes potentially important for embryo implantation and development of early pregnancy such as adhesion, immune response, placenta development, morphogenesis, cytoskeleton organization and others. The most interesting enriched terms from PGF2 $\alpha$-upregulated and PGF2 $\alpha$-downregulated clusters were visualized as a network (Fig. 3 ).

Using IPA on 577 DEGs, the most interesting overrepresented canonical pathways were associated with regulation of lipid metabolism, inflammation and cholesterol catabolism (LXR/RXR; $P=3.47 \mathrm{E}-06)$, as well as with integrin $(P=2.2 \mathrm{E}-04)$ and $\operatorname{mTOR}(P=1.701 \mathrm{E}-02)$ signaling (Supplementary Table 5 ). The main functional terms derived from IPA analysis showed similar results, compared to DAVID analysis, with highly involved functional terms such as embryonic development, inflammatory response, cellular growth and proliferation and lipid metabolism. (Supplementary Fig. 3 and Supplementary Table 6). Upstream analysis revealed that identified DEGs can be also regulated by factors other than PGF2 $\alpha$ factors (Supplementary Table 7). The most interesting factors potentially stimulating DEGs were estradiol-17 $\beta$, HOXA10 and TGFB1 and 2.

Effect of PGF2 $\alpha$ on the selected gene expression in porcine conceptuses

Validation of microarray results using qPCR confirmed expression of 14 out of 18 selected genes (IL1A, MFGE8, MMP2, SLCO2A1, STC2, ADAM9, AGER, AMBP, BMP2, LPAR1, MASP1, S100G, THBS1 and VTN), whereas four of them (KNG1, PROX1, DECR1 and TLR3) showed diverse expression in the qPCR to that detected by microarray analysis (Supplementary Table 8). Results from qPCR revealed that PGF2 $\alpha$ (100 nM) acting on trophoblast cells stimulated expression of ADAM9, VTN, LPAR1, BMP2, DECR 1 and THBS1 genes $(P<0.05)$. Treatment of the trophoblast cells with $1 \mu \mathrm{M}$ of PGF2 $\alpha$ resulted in increased expression of $A G E R, A M B P, B G N$, IL6R, S100G, TLR3 and MASP1 genes $(P<0.05)$ and in downregulation of MFGE8, SLCO2A1, TIMP1, TIMP2, KNG1, MMP9, SCT2 and TGFB3 gene expression $(P<0.05)$. Expression of IL1A, MMP2 and PROX1 genes was decreased in the trophoblast cells treated with both doses $(100 \mathrm{nM} ; 1 \mu \mathrm{M})$ of PGF2 $\alpha(P<0.05)$. Results from qPCR analyses are shown in the Fig. 4. Additionally, we evaluated the expression profile of MMP9 in conceptuses (days 10-17)/trophoblasts (days 18-25) at different stages of development. We found that the abundance of MMP9 mRNA was lowest at the period corresponding to maternal recognition of pregnancy (days 10-12 of pregnancy) and at the beginning of implantation 


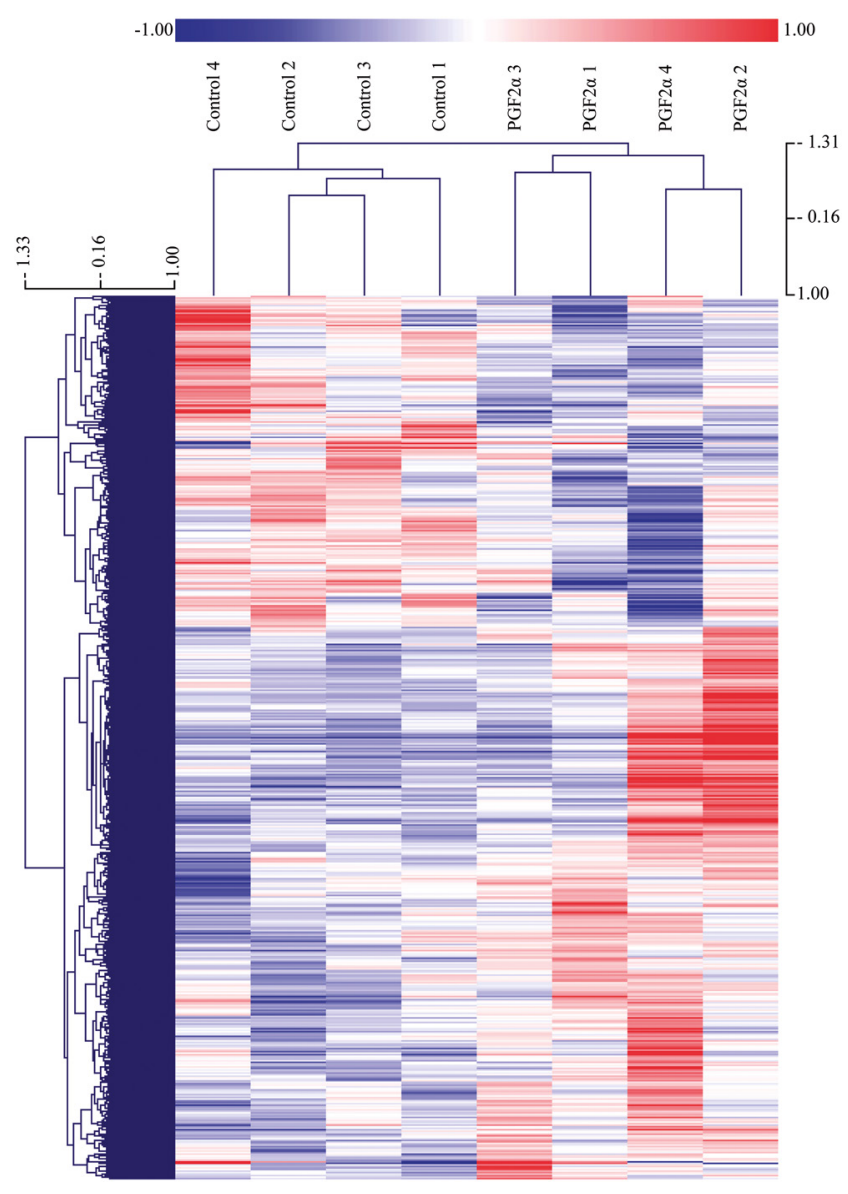

Figure 2 Heatmap showing microarray analysis of DEGs in PGF $2 \alpha-$ treated porcine trophoblast cells (PGF2 $\alpha 1-4$ ), and corresponding vehicle-treated controls (Control 1-4). Normalized expression data was clustered based on pairwise Pearson correlation using identified DEGs (red: correlation $=1$; blue: correlation $=-1$ ). 576 genes were differentially expressed between the two groups. A total of 360 genes were up-regulated and 216 genes were downregulated $(P<0.05)$. The full list of DEGs is provided in Supplementary Table 1.

(days 14-15). Expression of MMP9 was intermediate during implantation (days 16-19 of pregnancy) and markedly increased during placenta development (days $20-25$ of pregnancy; $P<0.05$; Fig. 4E).

\section{Experiment 3: PGF2 $\alpha$ stimulates adhesion and proliferation of the porcine trophoblast cells}

We demonstrated that PGF2 $\alpha(100 \mathrm{nM} ; 1 \mu \mathrm{M})$ acting through its receptor increased adhesion of trophoblast cells to fibronectin $(P<0.05 ;$ Fig. 5A). Stimulating effect of PGF $2 \alpha(100 \mathrm{nM}$ and $1 \mu \mathrm{M})$ was blocked by using PTGFR antagonist (AL8810). AL8810 used alone did not have any effect on cell adhesion.

During early pregnancy in mammals, rapid transformation of conceptus morphology and conceptus cell differentiation should be accompanied by increased cell proliferation. In the present study, we evaluated the influence of PGF $2 \alpha$ on conceptus cell proliferation during implantation period. We found that PGF2 $\alpha(100 \mathrm{nM})$ as well as its stable analog - fluprostenol (100 nM), acting through PTGFR-stimulated proliferation of porcine trophoblast cells $(P<0.05$; Fig. 5B). The effects of PGF $2 \alpha$ $(100 \mathrm{nM})$ and fluprostenol $(100 \mathrm{nM})$ were abolished by using AL8810. AL8810 used alone had effect similar to the control.

\section{Experiment 4: PGF2 $\alpha$ acting on trophoblast cells increases phosphorylation of factors potentially involved in adhesion and proliferation processes}

Since we previously indicated the involvement of FAK and MAPK (Waclawik et al. 2013) in adhesion of trophoblast cells and as MAPK signaling is also involved in cell proliferation, we determined whether PGF $2 \alpha$ may stimulate phosphorylation of these proteins in the trophoblast cells. In the present study, we demonstrated for the first time that PGF2 $\alpha$ stimulated phosphorylation of MAPK $1 / 3$ (Fig. 5C) and FAK (Fig. 5D) proteins $(P<0.05)$ in porcine trophoblast cells and that these effects were mediated through PGF2 $\alpha$ receptor (Fig. 5C and D).

\section{Discussion}

In the present study, we demonstrated for the first time the para- and/or autocrine mechanisms of prostaglandin F2 $\alpha$ action on conceptus/trophoblast cells during the implantation period. We also described the expression profile of PGF2 $\alpha$ receptor (PTGFR) in porcine conceptuses at different stages of their development.

Results from our experiments discussed below provide a new perspective on the role of PGF2 $\alpha$ in embryomaternal communication in the pig. We postulate that PGF2 $\alpha$, which is highly abundant in the uterine lumen during early pregnancy, is not an undesirable factor but instead is an important hormone supporting processes related to proper embryo development and implantation. In the present study, we examined, for the first time, the expression profiles of PTGFR mRNA and protein in porcine conceptuses/trophoblasts during early pregnancy. Maximal expression of the PTGFR gene in conceptuses/trophoblasts occurred during the implantation period. Similarly, increased abundance of PTGFR protein was observed on days 14-19 of pregnancy. These results concur with our previous findings that PGF2 $\alpha$ synthase protein expression is increased in conceptuses/trophoblasts from days 14 to 25 compared to days 10-12 of pregnancy (Waclawik \& Ziecik 2007). Strong signals of PTGFR protein expression are observed in the ovine trophectoderm on days 16, 18 and 20 of pregnancy (Dorniak et al. 2011). PGs secreted together with IFNT by ovine conceptuses regulate endometrial gene expression and functions that are important for conceptus growth and development (Dorniak et al. 2012). Our results are also consistent with transcriptomic data, in which expression of the PTGFR 
Table 3 Selected results of DAVID functional annotation clustering for differentially expressed genes in trophoblast cells treated with PGF2 $\alpha$.

\begin{tabular}{|c|c|}
\hline Selected functional terms of overrepresented annotation clusters & Enrichment score \\
\hline \multicolumn{2}{|l|}{ Upregulated } \\
\hline Focal adhesion (30; 3.67); cell adhesion (50; 1.48); protein binding involved in cell adhesion $(14 ; 2.29)$ & 3.96 \\
\hline Cell migration $(42 ; 1.79)$; regulation of cell motility $(28 ; 1.91)$ & 2.91 \\
\hline Response to hypoxia $(17 ; 3.01)$ & 2.84 \\
\hline Response to fibroblast growth factor $(10 ; 3.71)$; fibroblast growth factor receptor signaling pathway $(8 ; 4.01)$ & 2.53 \\
\hline $\begin{array}{l}\text { Response to growth factor }(28 ; 2.23) \text {; response to TGFB }(13 ; 3.05) \text {; transmembrane receptor protein serine/ } \\
\text { threonine kinase signaling pathway }(14 ; 2.19)\end{array}$ & 2.43 \\
\hline Regulation of cell proliferation $(19 ; 1.50)$ & 2.32 \\
\hline Response to steroid hormone $(16 ; 2.11)$ & 2.26 \\
\hline Anatomical structure formation involved in morphogenesis $(38 ; 1.67)$; angiogenesis $(17 ; 2.07)$ & 2.01 \\
\hline Regulation of MAP kinase activity $(18 ; 2.78)$; protein phosphorylation $(50 ; 1.36)$ & 1.95 \\
\hline Regulation of epithelial cell proliferation $(14 ; 2.35)$ & 1.68 \\
\hline Organ morphogenesis $(36 ; 1.83)$; epithelium development $(32 ; 1.52)$ & 1.52 \\
\hline ECM binding $(5 ; 4.72)$ & 1.35 \\
\hline \multicolumn{2}{|l|}{ Downregulated } \\
\hline Fatty acid biosynthetic process $(6 ; 3.38)$ & 2.71 \\
\hline Regulation of intracellular signal transduction $(34 ; 1.62)$ & 2.04 \\
\hline Steroid biosynthetic process $(7 ; 3.91)$ & 1.89 \\
\hline Cell migration $(28 ; 1.93)$ & 1.85 \\
\hline Anion transport $(14 ; 2.44)$ & 1.79 \\
\hline Regulation of cell proliferation $(31 ; 1.63)$ & 1.78 \\
\hline ECM organization $(11 ; 2.69)$ & 1.74 \\
\hline Female pregnancy $(8 ; 3.49)$ & 1.65 \\
\hline Cellular response to interferon gamma $(6 ; 3.63)$ & 1.34 \\
\hline Placenta development $(6 ; 3.38)$; reproductive structure development $(11 ; 2.15)$ & 1.35 \\
\hline
\end{tabular}

gene in day 14 filamentous conceptuses was 14-fold greater than in day 10 (spherical) and 12 (filamentous) conceptuses (Ross et al. 2009). Interestingly, we indicated the upregulation of endometrial PTGFR protein during the implantation period (Kaczynski \& Waclawik 2013). These results strongly support the hypothesis that PGF $2 \alpha$ secreted by the endometrium and conceptuses into the uterine lumen can act on trophoblasts in an auto- and/ or paracrine manner.

In the present study, we evaluated the effect of PGF2 $\alpha$ on global gene expression profiles in porcine conceptuses at the onset of the implantation period. Using different bioinformatics software, we were able to demonstrate that PGF2 $\alpha$ potentially affects a broad range of processes and functions related mainly with focal adhesion, ECM binding, cytoskeleton organization, cell migration and proliferation, but also with immune processes, metabolism, response to hypoxia, growth factor signaling and ion homeostasis. Intriguingly, similar processes (e.g., protein kinase regulator activity, cell motility, transport) identified in conceptuses undergoing the transition from day 12 to day 14 filamentous forms (Ross et al. 2009) were also observed in trophoblast cells treated with PGF2 $\alpha$. Moreover, it is interesting that analysis of potential upstream regulators of genes which were differentially regulated by PGF2 $\alpha$ revealed that these DEGs may also be regulated by other factors such as estradiol$17 \beta$, HOXA10 or TGFB, which are important players in the embryo-maternal dialog during early pregnancy (reviewed in Waclawik et al. 2017).
Due to the relatively low fold-change threshold for detection of DEGs, it is recommended to validate these results for corresponding DEGs if more in-depth studies are projected based on our transcriptomic analyses results. In the present study, we validated part of the microarray results using $\mathrm{qPCR}$ and functional in vitro experiments. Validation of expression of particular genes of interest (AGER, AMBP, MASP1, MFGE8, PROX1,

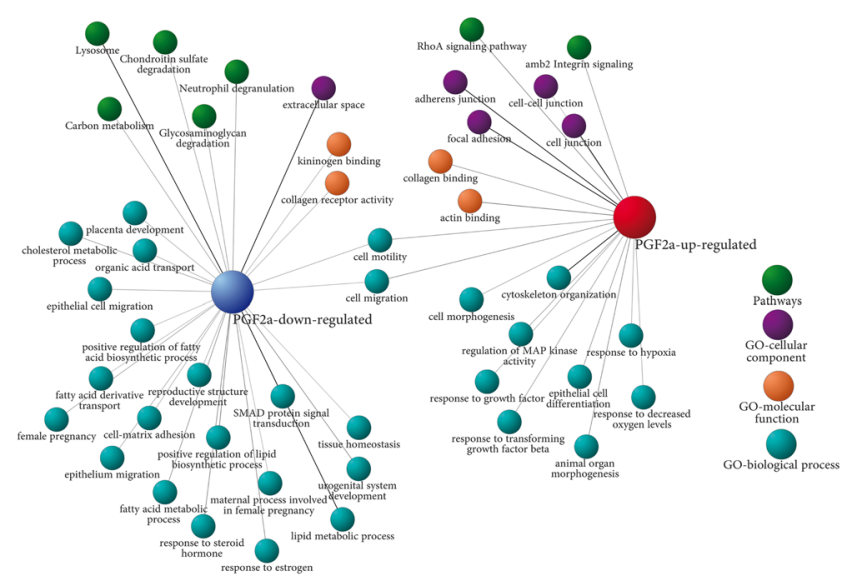

Figure 3 Functional map showing shared and treatment-specific functional annotation terms generated in multi-cluster gene functional enrichment analysis for DEGs identified in porcine primary trophoblast cells treated with PGF2 $\alpha$ or vehicle (control). Analysis was performed in ToppCluster software, functional map was edited and adjusted using Cytoscape. The redundant and noninformative terms were removed. Complete results are presented in tabular format in Supplementary Table 4. 

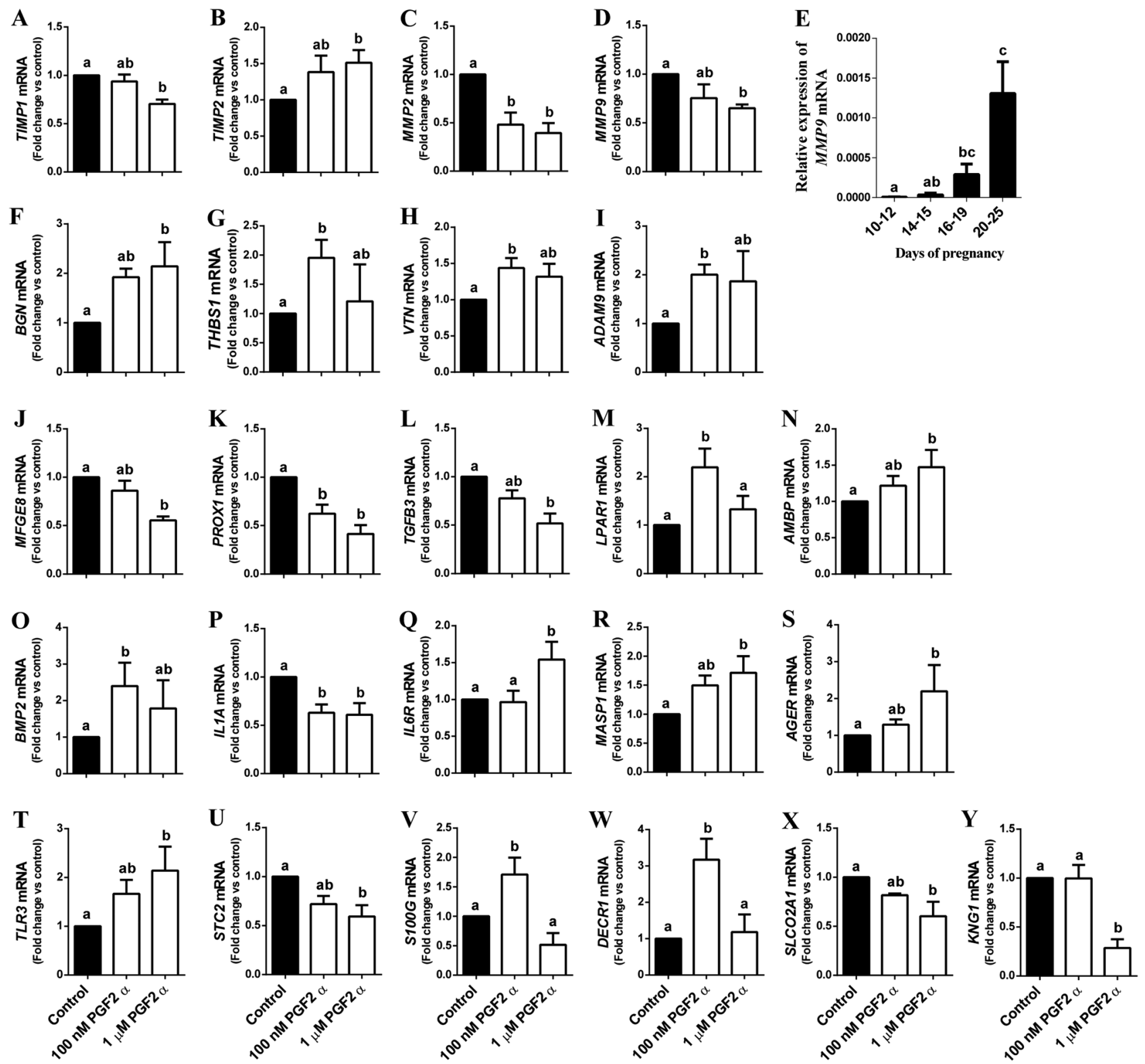

Figure 4 Expression of selected target genes determined by quantitative (real-time) RT-PCR in porcine primary trophoblast cells treated with PGF2 $\alpha(100 \mathrm{nM}, 1 \mu \mathrm{M})$ or vehicle (control). (A, B, C, D, F, G, H, I, J, K, L, M, N, O, P, Q, R, S, T, U, V, W, X and Y). ADAM9, ADAM metallopeptidase domain 9; $A G E R$, advanced glycosylation end-product specific receptor; $A M B P$, alpha-1-microglobulin/bikunin precursor; $B G N$, biglycan; $B M P 2$, bone morphogenetic protein 2; DECR1, 2,4-dienoyl-CoA reductase 1; IL1A, interleukin 1 alpha; IL6R, interleukin 6 receptor; $L P A R 1$, lysophosphatidic acid receptor 1; MASP1, mannan binding lectin serine peptidase 1; MFGE8, milk fat globule-EGF factor 8 protein; MMP2, matrix metallopeptidase 2; MMP9, matrix metallopeptidase 9; PROX1, prospero homeobox 1; S100G, S100 calcium binding protein G; SLCO2A1, solute carrier organic anion transporter family member $2 \mathrm{~A} 1$; STC2, stanniocalcin 2; TGFB3, transforming growth factor beta 3; THBS1, thrombospondin 1; TIMP1, metallopeptidase inhibitor 1; TIMP2, metallopeptidase inhibitor 2; TLR3, toll-like receptor 3; VTN, vitronectin. Expression of MMP9 mRNA in the porcine conceptuses/trophoblasts at different stages of development (E). Data on panels A, B, C, $D, F, G, H, I, J, K, L, M, N, O, P, Q, R, S, T, U, V, W, X$ and $Y$ are presented as means \pm s.E.M. of fold-change vs control (vehicle). Data on panel $E$ is presented as mean \pm S.E.M. Bars with different letter differ significantly $(P<0.05)$.

SLCO2A1, VTN, ADAM9, LPAR1, BMP2, DECR1, THBS, S100G, STC2, IL1A and TLR3) confirmed overall the results from the microarray analyses. Additionally, we analyzed the PGF2 $\alpha$-mediated expression of genes that are potentially important in embryo-maternal interactions during the implantation period $(B G N$,
MMP2, MMP9, TIMP1, TIMP2, KNG1, TGFB3, IL6, IL6R and TGFB3). Results of the microarray and qPCR analyses revealed that the PGF $2 \alpha$ affected the expression of genes related to processes crucial for successful implantation, such as ECM organization, ECM protein binding, focal adhesion, inflammatory response, cell 
A

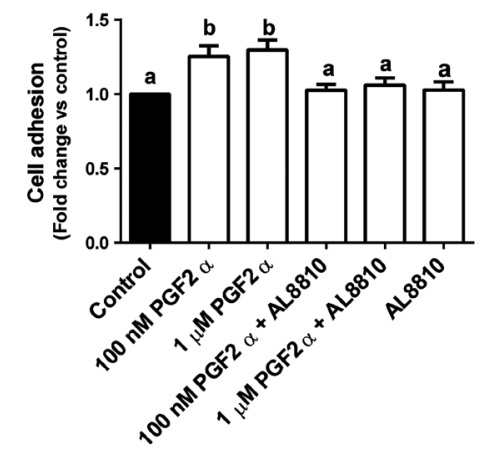

B
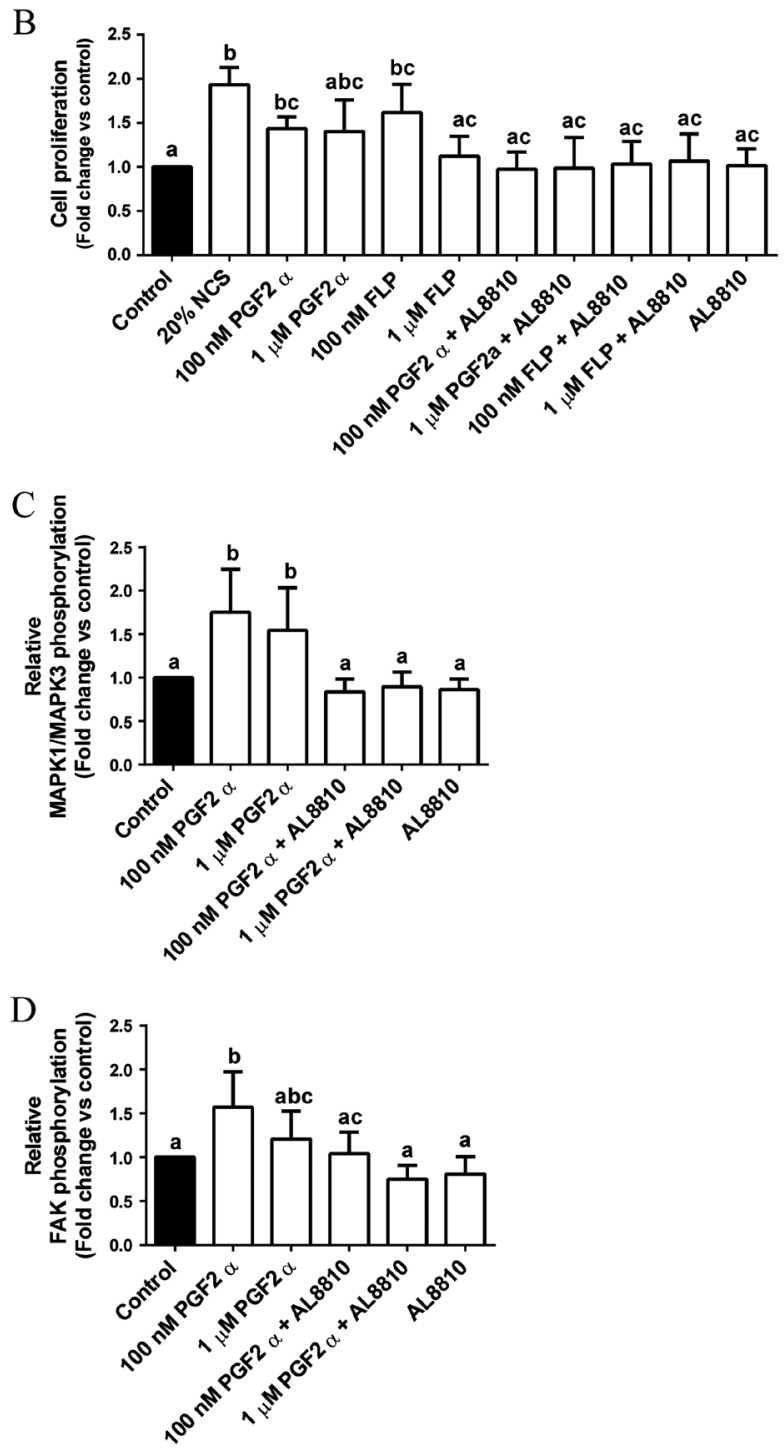

Figure 5 PGF2 $\alpha$ increased adhesion to ECM protein - fibronectin (A) and proliferation (B) of primary porcine trophoblast cells. Effect of PGF2 $\alpha$ on MAPK1/3 (C) and FAK (D) phosphorylation in porcine primary trophoblast cells in vitro. NCS-newborn calf serum (used as a positive control), AL8810, PTGFR antagonist; FLP, fluprostenol (stable prostaglandin F2 $\alpha$ analog). Data are presented as means \pm S.E.M. of fold-change vs control (vehicle). Different letters $(a, b$ and $c)$ indicate statistically significant differences $(P<0.05)$. proliferation, migration and motility or activation of intracellular protein kinases. Here, we briefly discuss the importance of validated genes in the most important processes accompanying the implantation process.

In all mammalian species, during the periimplantation period, formation of the placenta is preceded by adhesion of trophoblast cells to luminal epithelium of the endometrium (Geisert et al. 2015). This requires a profound rearrangement of endometrial tissue that is essential for successful implantation of embryos. Reorganization of tissue structures is related to processes such as ECM remodeling and vasculature development and is tightly controlled by a number of factors. Metalloproteinases are factors regulating ECM remodeling. MMPs together with their associated inhibitors (TIMPs) act concomitantly regulating aspects of reproductive function (reviewed in Curry \& Osteen 2003). MMP2 and MMP9 were reported to mediate human trophoblast cell invasion into matrigel in vitro (Bischof et al. 1995). Recently, we reported PGF2 $\alpha$ stimulated expression of the MMP9 gene in porcine endometrium, suggesting its involvement in ECM remodeling (Kaczyński et al. 2016). In this study, we observed a decrease in MMP2 and MMP9 mRNA content in porcine trophoblast cells in response to PGF2 $\alpha$ treatment. Simultaneously, we noticed that PGF2 $\alpha$ upregulated expression of the TIMP2 gene, which is an inhibitor of MMP2 and MMP9. These results correspond to the MMP9 gene expression profile in porcine conceptuses at different stages of development that was evaluated in the present study. Intriguingly, we found that PGF2 $\alpha$ acting on human trophoblast cells has an opposite effect, i.e. it increases MMP9 gene expression that is probably related to invasive type of implantation of human trophoblast (Baryla et al. 2017). We suggest that the downregulation of MMP2 and 9 and upregulation of TIMP2 mRNA expression in porcine conceptuses could be an effect of action of endometrium, which by secreting PGF2 $\alpha$ may protect the endometrial tissue against excessive degradation of its ECM, and this may be related to the non-invasive type of implantation specific for the pig. Moreover, we demonstrated that PGF2 $\alpha$ differentially regulated other genes (BGN, THBS, VTN, MFGE8, ADAM9, KNG1, $A M B P$ and $P R O X 1)$ that were reported to be involved in ECM remodeling, cell adhesion and proliferation in different mammalian species (Couchman et al. 1990, Bowen et al. 1996, Taylor et al. 1997, Hettinger et al. 2001, Bloor et al. 2002, Vonnahme et al. 2004, Kim et al. 2006, 2013, Kaczyński et al. 2016, Barua et al. 2017, Kolakowska et al. 2017). Results from functional in vitro experiments performed herein confirmed results from gene expression studies and support the conclusion that PGF2 $\alpha$ acting through its receptor in trophoblast cells stimulates adhesion of trophoblast cells to ECM proteins. Interestingly, we recently demonstrated that the role of PGE2 in increasing trophoblast adhesion is not 
species-specific because the mechanism is PTGER2 and integrin dependent in both porcine and human trophoblast cells (Waclawik et al. 2013). Moreover, iloprost (prostacyclin analog) acting through prostacyclin membrane receptors (PTGIR) stimulated porcine day 14 trophoblast cells to adhere to fibronectin (Morawska-Pucinska et al. 2014). Thus, the present report emphasizes the role of prostaglandins in proper control of the adhesion cascade during the implantation period in the pig.

During the peri-implantation period, porcine conceptuses undergo rapid transformation. On day 12 of pregnancy, trophoblasts elongate to more than $100 \mathrm{~mm}$ in length (Anderson 1978, Geisert et al. 1982). It has been stated that the conceptus elongation process is more dependent on cell outgrowth than cell division (Perry 1981). However, elongation is not the only process occurring during conceptus development. Cellular differentiation is also very important for embryonic development in all mammalian species. This process requires tight control over cell proliferation, migration and cell-cell interaction. The potential role of TGFB, LPA1, PROX1, AMBP and BMP2 in pregnancy establishment was reported in a number of mammals (McKeehan et al. 1986, Lee et al. 2007, Blitek et al. 2013, Kim et al. 2013, Jeong et al. 2016). Interestingly, IL6 which is mostly related to immunological processes has been reported to stimulate trophoblast cell proliferation and promote their adhesion to fibronectin (Blitek et al. 2012). In the present study, we found that PGF2 $\alpha$ did not affect IL6 mRNA; however, it increased IL6 receptor $(I L 6 R)$ mRNA content in porcine day 15 trophoblast cells. The present study is the first demonstrating the role of PGF $2 \alpha$ in promoting trophoblast cell proliferation in any mammalian species. We recently reported an indirect influence of PGF2 $\alpha$ on uterine endothelial cell proliferation (Kaczyński et al. 2016). Moreover, fluprostenol (PGF2 $\alpha$ analog) was reported to stimulate the expression of proteins related to proliferation of bovine endometrial cells (Zhang et al. 2017).

During the implantation period in some mammals, including pigs both pro- and anti-inflammatory processes are activated at the embryo-maternal interface and the proper balance between these two kinds of immunological responses is crucial for successful development of pregnancy (reviewed in Waclawik 2011). In the present study, we found that PGF2 $\alpha$ differentially regulated the expression of KNG1, MFGE8, AMBP, IL1, IL6R, MASP1, AGER and TLR3 genes that are involved in modulation of immunological processes in many species (Tuo et al. 1996, Vonnahme et al. 1999, Allen et al. 2002, Wang et al. 2007, Zhang et al. 2007, Berbaum et al. 2008, Prins et al. 2012, Tan et al. 2015). Thus, we infer that PGF2 $\alpha$ by differentially regulating genes in trophoblast cells may contribute to the control of immune interactions between developing conceptuses and the endometrium.
The importance and function of calcium during early embryo development and implantation have been well studied (reviewed in Whitaker 2006). Binding endometrial epithelial cells to trophoblast cells results in calcium influx in endometrial epithelial cells in humans (Tinel et al. 2000). In the porcine uterine lumen, concentration of calcium ions increases during the periimplantation period (Geisert et al. 1982). Bikunin, one of the products of the $A M B P$ gene, has been reported to inhibit the release of intracellular calcium ions induced by lipopolysaccharide (Kanayama et al. 1995). Stanniocalcin (STC), a glycoprotein regulating calcium homeostasis and has been suggested to be a luminal epithelial marker for implantation in pigs (Song et al. 2009). Another factor related to calcium ion homeostasis in endometrium during pregnancy is S100G protein also known as calbindin-d9k (Choi et al. 2009). Our data indicate that PGF2 $\alpha$ by regulating AMBP, STC2 and S100G gene expression in porcine conceptuses may be an upstream regulator of factors involved in calcium homeostasis. Our data suggest that in porcine conceptuses PGF2 $\alpha$ regulates MFGE8 and DECR1 which are involved in fatty acid metabolism, fatty acid resorption and placental transport (Kunau \& Dommes 1978, Marques et al. 2009, Khalifeh-Soltani et al. 2014).

Prostaglandin signaling is crucial for proper conceptus development (Kennedy et al. 2007, Dorniak et al. 2011). SLCO2A1 was suggested to play a critical role in supporting the establishment and maintenance of pregnancy by regulating PG transport at the maternalfetal interface in pigs. Expression of SLCO2A1 mRNA in day 15 conceptuses is decreased compared to day 12 conceptuses (Seo et al. 2014). Accordingly, we found down-regulation of SLCO2A1 gene expression in porcine trophoblast cells in response to PGF2 $\alpha$ treatment. This may suggest that PGF $2 \alpha$ by regulating its own transporter expression in trophoblast cells may autoregulate its secretion by conceptuses during implantation period.

Processes accompanying the implantation process such as cell adhesion and proliferation are triggered by activation of particular intracellular signaling pathways. Results from gene expression studies indicated that PGF2 $\alpha$-enriched terms related to activation of protein kinases, such as MAP kinase activity and protein phosphorylation. In the present study, we demonstrated that PGF2 $\alpha$ stimulated MAPK1/3 and FAK protein phosphorylation in trophoblast cells. Interestingly, PGF $2 \alpha$ has been reported to stimulate tyrosine phosphorylation of p125 FAK in NIH-3T3 cells (Watanabe et al. 1994) and in 293-EBNA cells stably expressing isoform A of the PTGFR prostanoid receptor (Pierce et al. 1999). PTGFR is a G-protein-coupled receptor activating Gq11 protein (Bos et al. 2004), and it has been demonstrated that genes upregulated at the end of gestation in a Goq/11-dependent manner in ovarian (granulosa/ luteal) cells included genes involved in focal adhesion and ECM interactions (Waite et al. 2016). Moreover, 
in human adenocarcinoma cells (Ishikawa cell line), PGF2 $\alpha$ was able to induce MAPK1/3 phosphorylation (Sales et al. 2005). We also found that PGE2 induced phosphorylation of MAPK1/3 and FAK. Taking all the above facts together, we speculate that PGF2 $\alpha$ acting through its receptor in trophoblast cells may activate Gq11 protein that leads to increased MAPK1/3 and FAK phosphorylation. This may result in enhanced adhesion of porcine trophoblast cells to ECM proteins.

In summary, the present study indicates a new role for PGF2 $\alpha$ secreted both by the conceptuses and endometrium during the implantation period in pigs. Results from global gene expression profiling indicate that PGF $2 \alpha$ acting in an auto- and/or paracrine manner is involved in processes important for conceptus development and attachment to the uterine epithelium (cell proliferation and focal adhesion, ECM binding, cell migration, cytoskeleton organization, immune interactions, ion homeostasis, metabolism, activation of TGFB and FGF signaling pathways, response to hypoxia). Functional in vitro experiments confirmed insights from transcriptomic studies, allowing us to conclude that PGF2 $\alpha$ by inducing transcriptomic changes in porcine trophoblast cells affects a broad range of processes potentially involved in implantation and development of the placenta, particularly activation of intracellular protein kinases (MAPK, FAK) and stimulation of trophoblast cell adhesion and proliferation.

\section{Supplementary data}

This is linked to the online version of the paper at https://doi.org/10.1530/REP-18-0225.

\section{Declaration of interest}

The authors declare that there is no conflict of interest that could be perceived as prejudicing the impartiality of the research reported.

\section{Funding}

This research was supported by grant 2012/05/E/NZ9/03493 from the National Science Centre in Poland. P Kaczynski was supported by the grant of KNOW Consortium "Healthy Animal - Safe Food", MS\&HE Decision No. 05-1/KNOW2/2015. A Waclawik was supported by the SRF Academic Scholarship Award 2017 from the Society for Reproduction and Fertility.

\section{Acknowledgements}

The authors would like to thank Katarzyna Gromadzka-Hliwa, Jan Klos and Michal Blitek (Institute of Animal Reproduction and Food Research, Polish Academy of Sciences) for their help in technical assistance, handling of animals and collecting samples. They are grateful to Andrea Klanner (Gene Center,
LMU, Munich) for excellent technical assistance in microarray experiment. They would like to thank Mr Jochen Bick (D-USYS, ETH Zurich) for his help in microarray annotation update.

\section{References}

Allen MR, Zhang BR, Hettinger AM, Goad DW, Malayer JR \& Geisert RD 2002 Detection of bradykinin and bradykinin-b2 receptors in the porcine endometrium during the estrous cycle and early pregnancy. Biology of Reproduction 66 574-579. (https://doi.org/10.1095/biolreprod66.3.574)

Andersen CL, Jensen JL \& Ørntoft TF 2004 Normalization of real-time quantitative reverse transcription-PCR data: a model-based variance estimation approach to identify genes suited for normalization, applied to bladder and colon cancer data sets. Cancer Research 64 5245-5250. (https://doi.org/10.1158/0008-5472.CAN-04-0496)

Anderson LL 1978 Growth, protein content and distribution of early pig embryos. Anatomical Record 190 143-153 (https://doi.org/10.1002/ ar.1091900112)

Barua S, Macedo A, Kolb DS, Wynne-Edwards KE \& Klein C 2017 Milk-fat globule epidermal growth factor 8 (MFGE8) is expressed at the embryoand fetal-maternal interface in equine pregnancy. Reproduction Fertility and Development 30 585-590. (https://doi.org/10.1071/RD17094)

Baryla M, Kaczynski P \& Waclawik A 2017 Prostaglandin F2 $\alpha$ regulates adhesion of HTR8/SVneo trophoblast cell line. Fertility 2017 Conference Materials 64.

Bazer FW \& Thatcher WW 1977 Theory of maternal recognition of pregnancy in swine based on estrogen controlled endocrine versus exocrine secretion of prostaglandin F2 $\alpha$ by the uterine endometrium. Prostaglandins 14 397-400. (https://doi.org/10.1016/0090-6980(77) 90185-X)

Berbaum K, Shanmugam K, Stuchbury G, Wiede F, Körner H \& Münch G 2008 Induction of novel cytokines and chemokines by advanced glycation end products determined with a cytometric bead array. Cytokine 41 198-203. (https://doi.org/10.1016/j.cyto.2007.11.012)

Bischof P, Martelli M, Campana A, Itoh Y, Ogata Y \& Nagase H 1995 Importance of matrix metalloproteinases in human trophoblast invasion. Early Pregnancy 1 263-239.

Blitek A, Morawska-Pucinska E, Szymanska M, Kiewisz J \& Waclawik A 2013 Effect of conceptus on transforming growth factor (TGF) $\beta 1$ mRNA expression and protein concentration in the porcine endometrium--in vivo and in vitro studies. Journal of Reproduction and Development 59 512-519. (https://doi.org/10.1262/jrd.2013-002)

Blitek A, Morawska E \& Ziecik AJ 2012 Regulation of expression and role of leukemia inhibitory factor and interleukin-6 in the uterus of early pregnant pigs. Theriogenology 78 951-964. (https://doi.org/10.1016/j. theriogenology.2012.05.016)

Bloor DJ, Metcalfe AD, Rutherford A, Brison DR \& Kimber SJ 2002 Expression of cell adhesion molecules during human preimplantation embryo development. Molecular Human Reproduction 8 237-245. (https://doi.org/10.1093/molehr/8.3.237)

Bos CL, Richel DJ, Ritsema T, Peppelenbosch MP \& Versteeg H 2004 Prostanoids and prostanoid receptors in signal transduction. International Journal of Biochemistry and Cell Biology 36 1187-1205. (https://doi. org/10.1016/j.biocel.2003.08.006)

Bowen JA, Bazer FW \& Burghardt RC 1996 Spatial and temporal analyses of integrin and Muc-1 expression in porcine uterine epithelium and trophectoderm in vivo. Biology of Reproduction 55 1098-1106. (https:// doi.org/10.1095/biolreprod55.5.1098)

Choi Y, Seo H, Kim M \& Ka H 2009 Dynamic expression of calciumregulatory molecules, TRPV6 and S100G, in the uterine endometrium during pregnancy in pigs. Biology of Reproduction 81 1122-1130. (https://doi.org/10.1095/biolreprod.109.076703)

Couchman JR, Austria MR \& Woods A 1990 Fibronectin-cell interactions. Journal of Investigative Dermatology 94(Supplement 6) 7S-14S. (https:// doi.org/10.1111/1523-1747.ep12874973)

Curry TE Jr \& Osteen KG 2003 The matrix metalloproteinase system: changes, regulation, and impact throughout the ovarian and uterine reproductive cycle. Endocrine Reviews 24 428-465. (https://doi. org/10.1210/er.2002-0005)

Dorniak P, Bazer FW \& Spencer TE 2011 Prostaglandins regulate conceptus elongation and mediate effects of interferon tau on the ovine 
uterine endometrium. Biology of Reproduction 84 1119-1127. (https:// doi.org/10.1095/biolreprod.110.089979)

Dorniak P, Bazer FW, Wu G \& Spencer TE 2012 Conceptus-derived prostaglandins regulate endometrial function in sheep. Biology of Reproduction 9 1-7. (https://doi.org/10.1095/biolreprod.112.100487)

Erdem H \& Guzeloglu A 2010 Effect of meloxicam treatment during early pregnancy in Holstein heifers. Reproduciton in Domestic Animals 45 625-628. (https://doi.org/10.1111/j.1439-0531.2008.01317.x)

Geisert RD, Rasby RD, Minton JE \& Wetteman RP 1986 Role of prostaglandins in development of porcine blastocysts. Prostaglandins $\mathbf{3 1}$ 191-203. (https://doi.org/10.1016/0090-6980(86)90046-8)

Geisert RD, Zavy MT, Moffatt RJ, Blair RM \& Yellin T 1990 Embryonic steroids and the establishment of pregnancy in pigs. Journal of Reproduction and Fertility Supplement 40 293-305.

Geisert AD, Johnson GA \& Burghardt RC 2015 Implantation and establishment of pregnancy in the pig. In: Regulation of Implantation and Establishment of Pregnancy in Mammals. Advances in Anatomy Embryology and Cell Biology, pp 137-182. Eds RD Geisert, FW Bazer. Switzerland: Springer International Publishing. (https://doi. org/10.1007/978-3-319-15856-3_8)

Geisert RD, Renegar RH, Thatcher WW, Roberts RM \& Bazer FW 1982 Establishment of pregnancy in the pig: I. Interrelationships between preimplantation development of the pig blastocyst and uterine endometrial secretions. Biology of Reproduction 27 925-939. (https:// doi.org/10.1095/biolreprod27.4.925)

Hackstadt AJ \& Hess AM 2009 Filtering for increased power for microarray data analysis. BMC Bioinformatics 10 11. (https://doi.org/10.1186/14712105-10-11)

Hettinger AM, Allen MR, Zhang BR, Goad DW, Malayer JR \& Geisert RD 2001 Presence of the acute phase protein, bikunin, in the endometrium of gilts during estrous cycle and early pregnancy. Biology of Reproduction 65 507-513. (https://doi.org/10.1095/biolreprod65.2.507)

Huang DW, Sherman BT \& Lempicki RA 2009a Bioinformatics enrichment tools: paths toward the comprehensive functional analysis of large gene lists. Nucleic Acids Research 37 1-13. (https://doi.org/10.1093/nar/gkn923)

Huang DW, Sherman BT \& Lempicki RA 2009b Systematic and integrative analysis of large gene lists using DAVID Bioinformatics Resources. Nature Protocols 4 44-57. (https://doi.org/10.1038/nprot.2008.211)

Huber W, von Heydebreck A, Sultmann H, Poustka A \& Vingron M 2002 Variance stabilization applied to microarray data calibration and to the quantification of differential expression. Bioinformatics 18 (Supplement 1) S96-S104. (https://doi.org/10.1093/bioinformatics/18.suppl_1.S96)

Jeong W, Seo H, Sung Y, Ka H, Song G \& Kim J 2016 Lysophosphatidic acid (LPA) receptor 3-mediated LPA signal transduction pathways: a possible relationship with early development of peri-implantation porcine conceptus. Biology of Reproduction 104 1-11.

Johnson GA, Burghardt RC, Bazer FW \& Spencer TE 2003 Minireview: osteopontin: roles in implantation and placentation. Biology of Reproduction 69 1458-1471. (https://doi.org/10.1095/ biolreprod.103.020651)

Kaczynski P \& Waclawik A 2013 Effect of conceptus on expression of prostaglandin F2 $\alpha$ receptor in the porcine endometrium. Theriogenology 79 784-790. (https://doi.org/10.1016/j.theriogenology.2012.12.003)

Kaczyński P, Kowalewski MP \& Waclawik A 2016 Prostaglandin F2 $\alpha$ promotes angiogenesis and embryo-maternal interactions during implantation. Reproduction 151 539-552. (https://doi.org/10.1530/REP15-0496)

Kaimal V, Bardes EE, Tabar SC, Jegga AG \& Aronow BJ 2010 ToppCluster: a multiple gene list feature analyzer for comparative enrichment clustering and network-based dissection of biological systems. Nucleic Acids Research 38 (Web Server issue) W96-W102. (https://doi.org/10.1093/ nar/gkq418)

Kanayama N, Halim A, Maehara K, Kajiwara Y, Fujie M \& Terao T 1995 Kunitz-type trypsin inhibitor prevents LPS-induced increase of cytosolic free $\mathrm{Ca} 2+$ in human neutrophils and HUVEC cells. Biochemical and Biophysical Research Communications 207 324-330. (https://doi. org/10.1006/bbrc.1995.1191)

Kennedy TG, Gillio-Meina C \& Phang SH 2007 Prostaglandins and the initiation of blastocyst implantation and decidualization. Reproduction 134 635-643. (https://doi.org/10.1530/REP-07-0328)

Khalifeh-Soltani A, McKleroy W, Sakuma S, Cheung YY, Tharp K, Qiu Y, Turner SM, Chawla A, Stahl A \& Atabai K 2014 Mfge8 promotes obesity by mediating the uptake of dietary fats and serum fatty acids. Nature Medicine 20 175-183. (https://doi.org/10.1038/nm.3450)

Kim H, Cruz M, Bourdeau A \& Dumont DJ 2013 Cell-cell interactions influence vascular reprogramming by Prox1 during embryonic development. PLOS ONE 8 e52197. (https://doi.org/10.1371/journal. pone.0052197)

Kim J, Kang SG, Kim JI, Park JH, Kim SK, Cho DJ \& Kim H 2006 Implication of ADAM-8, -9, -10,-12,-15,-17, and ADAMTS-1 in implantational remodeling of a mouse uterus. Yonsei Medical Journal 47 558-567. (https://doi.org/10.3349/ymj.2006.47.4.558)

Kolakowska J, Souchelnytskyi S, Saini RKR \& Franczak A 2017 Proteomic analysis of the endometrium during early pregnancy in the domestic pig. Reproduction Fertility and Development 29 2255-2268. (https://doi. org/10.1071/RD16435)

Kowalewski MP, Kautz E, Högger E, Hoffmann B \& Boos A 2014 Interplacental uterine expression of genes involved in prostaglandin synthesis during canine pregnancy and at induced prepartum luteolysis/ abortion. Reproductive Biology and Endocrinology 12 46. (https://doi. org/10.1186/1477-7827-12-46)

Kraeling RR, Rampacek GB \& Fiorello NA 1985 Inhibition of pregnancy with indomethacin in mature gilts and prepuberal gilts induced to ovulate. Biology of Reproduction 32 105-110. (https://doi.org/10.1095/ biolreprod32.1.105)

Kunau WH \& Dommes P 1978 Degradation of unsaturated fatty acids. Identification of intermediates in the degradation of cis-4-decenoylCoA by extracts of beef-liver mitochondria. European Journal of Biochemistry 91 533-544. (https://doi.org/10.1111/j.1432-1033.1978. tb12707.x)

Lee KY, Jeong JW, Wang J, Ma L, Martin JF, Tsai SY, Lydon JP \& DeMayo FJ 2007 Bmp2 is critical for the murine uterine decidual response. Molecular and Cellular Biology 27 5468-5478. (https://doi.org/10.1128/ MCB.00342-07)

Marques E, Nkrumah JD, Sherman EL \& Moore SS 2009 Polymorphisms in positional candidate genes on BTA14 and BTA26 affect carcass quality in beef cattle. Journal of Animal Science 87 2475-2484. (https://doi. org/10.2527/jas.2008-1456)

McCracken JA, Custer EE \& Lamsa JC 1999 Luteolysis: a neuroendocrinemediated event. Physiological Reviews 79 263-323. (https://doi. org/10.1152/physrev.1999.79.2.263)

McKeehan WL, Sakagami Y, Hoshi H \& McKeehan KA 1986 Two apparent human endothelial cell growth factors from human hepatoma cells are tumor-associated proteinase inhibitors. Journal of Biological Chemistry 261 5378-5383.

Morawska-Pucinska E, Szymanska M \& Blitek A 2014 Expression profile and role of prostacyclin receptor (PTGIR) in peri-implantation porcine conceptuses. Theriogenology 82 546-556. (https://doi.org/10.1016/j. theriogenology.2014.05.014)

Perry JS 1981 The mammalian fetal membranes. Journal of Reproduction and Fertility 62 321-335. (https://doi.org/10.1530/jrf.0.0620321)

Pierce KL, Fujino H, Srinivasan D \& Regan JW 1999 Activation of FP prostanoid receptor isoforms leads to Rho-mediated changes in cell morphology and in the cell cytoskeleton. Journal of Biological Chemistry 274 35944-35949. (https://doi.org/10.1074/jbc.274.50.35944)

Prins JR, Gomez-Lopez N \& Robertson SA 2012 Interleukin-6 in pregnancy and gestational disorders. Journal of Reproductive Immunology 95 1-14. (https://doi.org/10.1016/j.jri.2012.05.004)

Ross JW, Ashworth MD, Stein DR, Couture OP, Tuggle CK \& Geisert RD 2009 Identification of differential gene expression during porcine conceptus rapid trophoblastic elongation and attachment to uterine luminal epithelium. Physiological Genomics 36 140-148. (https://doi. org/10.1152/physiolgenomics.00022.2008)

Saeed AI, Sharov V, White J, Li J, Liang W, Bhagabati N, Braisted J, Klapa M, Currier T, Thiagarajan M et al. 2003 TM4: a free, open-source system for microarray data management and analysis. Biotechniques $\mathbf{3 4}$ 374-378.

Sales KJ, List T, Boddy SC, Williams AR, Anderson RA, Naor Z \& Jabbour HN 2005 A novel angiogenic role for prostaglandin F2alphaFP receptor interaction in human endometrial adenocarcinomas. Cancer Research 65 7707-7716. (https://doi.org/10.1158/0008-5472.CAN-050101)

Seo H, Choi Y, Shim J, Yoo I \& Ka H 2014 Prostaglandin transporters ABCC4 and SLCO2A1 in the uterine endometrium and conceptus 
during pregnancy in pigs. Biology of Reproduction 100 1-10. (https:// doi.org/10.1095/biolreprod.113.114934)

Smyth GK 2004 Linear models and empirical bayes methods for assessing differential expression in microarray experiments. Statistical Applications in Genetics and Molecular Biology 3 Article3.

Song G, Dunlap KA, Kim J, Bailey DW, Spencer TE, Burghardt RC, Wagner GF, Johnson GA \& Bazer FW 2009 Stanniocalcin 1 is a luminal epithelial marker for implantation in pigs regulated by progesterone and estradiol. Endocrinology 150 936-945. (https://doi.org/10.1210/ en.2008-1026)

Tan Y, AlKhamees B, Jia D, Li L, Couture JF, Figeys D, Jinushi M \& Wang L 2015 MFG-E8 Is Critical for Embryonic Stem Cell-Mediated T Cell Immunomodulation. Stem Cell Reports 5 741-752. (https://doi. org/10.1016/j.stemcr.2015.09.005)

Taylor MR, Couto JR, Scallan CD, Ceriani RL \& Peterson JA 1997 Lactadherin (formerly BA46), a membrane-associated glycoprotein expressed in human milk and breast carcinomas, promotes Arg-Gly-Asp (RGD)-dependent cell adhesion. DNA Cell Biology 16 861-869. (https:// doi.org/10.1089/dna.1997.16.861)

Tinel H, Denker HW \& Thie M 2000 Calcium influx in human uterine epithelial RL95-2 cells triggers adhesiveness for trophoblast-like cells: model studies on signalling events during embryo implantation. Molecular Human Reproduction 6 1119-1130. (https://doi.org/10.1093/ molehr/6.12.1119)

Tuo W, Harney JP \& Bazer FW 1996 Developmentally regulated expression of interleukin-1 beta by peri-implantation conceptuses in swine. Journal of Reproductive Immunology 31 185-198. (https://doi. org/10.1016/0165-0378(96)00975-8)

Ulbrich SE, Schulke K, Groebner AE, Reichenbach HD, Angioni C, Geisslinger G \& Meyer HH 2009 Quantitative characterization of prostaglandins in the uterus of early pregnant cattle. Reproduction 138 371-382. (https://doi.org/10.1530/REP-09-0081)

Vilella F, Ramirez L, Berlanga O, Martínez S, Alamá P, Meseguer M, Pellicer A \& Simón C 2013 PGE2 and PGF2 $\alpha$ concentrations in human endometrial fluid as biomarkers for embryonic implantation. Journal of Clinical Endocrinology and Metabolism 98 4123-4132. (https://doi. org/10.1210/jc.2013-2205)

Vonnahme KA, Fernando SC, Ross JW, Ashworth MD, DeSilva U, Malayer JR \& Geisert RD 2004 Porcine endometrial expression of kininogen, factor XII, and plasma kallikrein in cyclic and pregnant gilts. Biology of Reproduction 70 132-138. (https://doi.org/10.1095/ biolreprod.103.020412)

Vonnahme KA, Malayer JR, Spivey HO, Ford SP, Clutter AC \& Geisert RD 1999 Detection of kallikrein gene expression and enzymatic activity in porcine endometrium during the estrous cycle and early pregnancy. Biology of Reproduction 61 1235-1241. (https://doi.org/10.1095/ biolreprod61.5.1235)

Waclawik A 2011 Novel insights into the mechanisms of pregnancy establishment: regulation of prostaglandin synthesis and signaling in the pig. Reproduction 142 389-399. (https://doi.org/10.1530/REP-11-0033)

Waclawik A \& Ziecik AJ 2007 Differential expression of prostaglandin (PG) synthesis enzymes in conceptus during peri-implantation period and endometrial expression of carbonyl reductase/PG 9-ketoreductase in the pig. Journal of Endocrinology 194 499-510. (https://doi.org/10.1677/ JOE-07-0155)

Waclawik A, Kaczynski P \& Jabbour HN 2013 Autocrine and paracrine mechanisms of prostaglandin $\mathrm{E}_{2}$ action on trophoblast/conceptus cells through the prostaglandin $\mathrm{E}_{2}$ receptor (PTGER2) during implantation. Endocrinology 154 3864-3876. (https://doi.org/10.1210/en.2012-2271)

Waclawik A, Rivero-Muller A, Blitek A, Kaczmarek MM, Brokken LJ, Watanabe K, Rahman NA \& Ziecik AJ 2006 Molecular cloning and spatiotemporal expression of prostaglandin $\mathrm{F}$ synthase and microsomal prostaglandin E synthase-1 in porcine endometrium. Endocrinology 147 210-221. (https://doi.org/10.1210/en.2005-0880)

Waclawik A, Jabbour HN, Blitek A \& Ziecik AJ 2009 Estradiol-17beta, prostaglandin E2 (PGE2), and the PGE2 receptor are involved in PGE2 positive feedback loop in the porcine endometrium. Endocrinology 150 3823-3832. (https://doi.org/10.1210/en.2008-1499)

Waclawik A, Kaczmarek MM, Kowalczyk AE, Bogacki M \& Ziecik AJ 2008 Expression of prostaglandin synthesis pathway enzymes in the porcine corpus luteum during the oestrous cycle and early pregnancy. Theriogenology 70 145-152. (https://doi.org/10.1016/j. theriogenology.2008.03.008)

Waclawik A, Kaczmarek MM, Blitek A, Kaczynski P \& Ziecik AJ 2017 Embryo-maternal dialogue during pregnancy establishment and implantation in the pig. Molecular Reproduction and Development $\mathbf{8 4}$ 842-855. (https://doi.org/10.1002/mrd.22835)

Waite C, Mejia R \& Ascoli M 2016 Gq/11-dependent changes in the murine ovarian transcriptome at the end of gestation. Biology of Reproduction 94 62. (https://doi.org/10.1095/biolreprod.115.136952)

Wang CC, Yim KW, Poon TC, Choy KW, Chu CY, Lui WT, Lau TK, Rogers MS \& Leung TN 2007 Innate immune response by ficolin binding in apoptotic placenta is associated with the clinical syndrome of preeclampsia. Clinical Chemistry 53 42-52. (https://doi.org/10.1373/ clinchem.2007.074401)

Wang Y, Zhao AM \& Lin QD 2010 Role of cyclooxygenase-2 signaling pathway dysfunction in unexplained recurrent spontaneous abortion. Chinese Medical Journal 123 1543-1547.

Watanabe T, Nakao A, Emerling D, Hashimoto Y, Tsukamoto K, Horie Y, Kinoshita M \& Kurokawa K 1994 Prostaglandin F2 alpha enhances tyrosine phosphorylation and DNA synthesis through phospholipase C-coupled receptor via $\mathrm{Ca}(2+)$-dependent intracellular pathway in $\mathrm{NIH}$ $3 T 3$ cells. Journal of Biological Chemistry 269 17619-17625.

Whitaker M 2006 Calcium at fertilization and in early development. Physiological Reviews $86 \quad 25-88 . \quad$ (https://doi.org/10.1152/ physrev.00023.2005)

Zavy MT, Bazer FW, Thatcher WW \& Wilcox CJ 1980 A study of prostaglandin $\mathrm{F} 2 \alpha$ as the luteolysin in swine: V. Comparison of prostaglandin $F$, progestins, estrone and estradiol in uterine flushings from pregnant and nonpregnant gilts. Prostaglandins 20 837-851. (https://doi.org/10.1016/0090-6980(80)90137-9)

Zhang J, Sun R, Wei H, Wu D \& Tian Z 2007 Toll-like receptor 3 agonist enhances IFN-gamma and TNF-alpha production by murine uterine NK cells. International Immunopharmacology 7 588-596. (https://doi. org/10.1016/j.intimp.2006.12.014)

Zhang S, Liu B, Gao L, Mao W, Fu C, Duritahala D, Zhang N, Zhang Y, Shen Y \& Cao J 2017 Prostaglandin F2 $\alpha$-PTGFR signaling activation, growth factor expression and cell proliferation in bovine endometrial explants. Reproduction Fertility and Development 29 2195-2205. (https://doi.org/10.1071/RD17111)

Zhao S \& Fernald RD 2005 Comprehensive algorithm for quantitative realtime polymerase chain reaction. Journal of Computational Biology 12 1047-1064. (https://doi.org/10.1089/cmb.2005.12.1047)

Received 4 May 2018

First decision 29 May 2018

Revised manuscript received 6 August 2018

Accepted 10 August 2018 